\title{
Comparisons of Herbicide Treated and Cultivated Herbicide-Resistant Corn
}

\author{
H. Arnold Bruns and Hamed K. Abbas \\ Crop Genetics and Production Research Unit, ARS, USDA P.O. Box 345, Stoneville, MS 38776, USA \\ Correspondence should be addressed to H. Arnold Bruns, arnold.bruns@ars.usda.gov
}

Received 6 October 2009; Accepted 7 May 2010

Academic Editor: Stephen Herbert

Copyright $\odot 2010$ H. A. Bruns and H. K. Abbas. This is an open access article distributed under the Creative Commons Attribution License, which permits unrestricted use, distribution, and reproduction in any medium, provided the original work is properly cited.

\begin{abstract}
Four glyphosate resistant corn (Zea mays L.) hybrids, a glufosinate-ammonium resistant hybrid, and a conventional atrazine resistant hybrid gown at Stoneville, MS in 2005, 2006, and 2007 with furrow irrigation were treated with their respective herbicides and their growth, yield, and mycotoxin incidence were compared with untreated cultivated plots. Leaf area index (LAI) and dry matter accumulation (DMA) were collected on a weekly basis beginning at growth stage V3 and terminating at anthesis. Crop growth rates (CRGs) and relative growth rates (RGRs) were calculated. Plots were later harvested, yield and yield component data collected, and kernel samples analyzed for aflatoxin and fumonisin. Leaf area index, DMA, CRG, and RGR were not different among the herbicide treated plots and from those that were cultivated. Curves for LAI and DMA were similar to those previously reported. Aflatoxin and fumonisin were relatively low in all plots. Herbicide application or the lack thereof had no negative impact on the incidence of kernel contamination by these two mycotoxins. Herbicides, especially glyphosate on resistant hybrids, have no negative effects on corn yields or kernel quality in corn produced in a humid subtropical environment.
\end{abstract}

\section{Introduction}

Herbicides have been a standard method of weed control in corn for over five decades, especially with the introduction of relatively low-cost and effective soil-applied pre-emergence compounds [1]. Atrazine, [2-Chloro-4ethylamino-6-isopropylamino-1,3,5-triazine] allowed producers to increase their profits by chemically controlling a large number of weed species that robbed corn of needed water, light, and nutrients. The advent of corn hybrids resistant to the herbicide glyphosate [N(phosphonomethyl)glycine] has expanded the number of weed species that can be chemically controlled, including several noxious pests not controlled by other corn herbicides. Corn hybrids are also available that are resistant to the herbicide glufosinate-ammonium [2-amino-4(hydroxymethylphosphinyl) butanoic acid] which has nearly as broad of a range of weed species controlled as glyphosate. Virtually all major seed corn companies now offer hybrids in all maturity ranges resistant to one or the other of these two latter herbicides. As of 2005, glyphosate-resistant hybrids were grown on nearly $40 \%$ of the total U.S. corn hectarage while glufosinate-ammonium-resistant hybrids were produced on about $7 \%$ of the total corn hectarage [2]. Atrazine was applied to about $66 \%$ of the total U.S. corn hectarage.

Glyphosate's mode of action involves the eventual interference in the synthesis of the amino acids phenylalanine, tyrosine, and tryptophan leading to plant cell death [3]. Glufosinate-ammonium functions by inhibiting glutamine synthetase which is necessary for the production of glutamine and ammonia detoxification [4]. This leads to disruption of photosynthesis and eventual plant cell death [5]. Genetic resistance to these two herbicides in crop species have been developed by Monsanto [Glyphosate] and Bayer [glufosinate-ammonium] and currently remain under patent protection. Atrazine was introduced as an herbicide in 1952 and is lethal to susceptible plants by blocking electron flow in noncyclic photophosphorylation [6].

Mixed results on corn grain yields of glyphosate resistant hybrids compared to hybrids without glyphosate resistance grown using conventional weed control systems have been 
Table 1: Hybrids Used to Evaluate Effects of Herbicides on Corn Growth and Development at Stoneville, MS.

\begin{tabular}{lcc}
\hline Hybrid & \multicolumn{2}{c}{ Maturity $^{\dagger}$} \\
\hline DKC 60-17RR $^{\ddagger}$ & 1471 & days \\
DKC 60-19RR $^{\ddagger}$ & 1471 & 110 \\
G8118RR & 1624 & 110 \\
G8287RR & 1540 & 120 \\
G8270RR & 1571 & 116 \\
31G98 & 1556 & 118 \\
34A55LL & 1471 & 117 \\
\hline
\end{tabular}

${ }^{\dagger}$ Data from companies' sales literature. RR suffix denotes glyphosate resistance.

${ }^{\ddagger}$ Monsanto St. Louis, MO.

$\S$ Garst Seed Company, Slater, IA.

"G8287RR planted in 2005 and 2006. G8270RR planted in 2007.

\#Pioneer International, Johnston, IA.

${ }^{\dagger \dagger}$ Glyphosate and glufosinate-ammonium intolerant hybrid treated with Atrazine.

${ }^{\ddagger \ddagger}$ LL suffix denotes glufosinate-ammonium tolerant hybrid.

reported. Ferrell and Witt [7] determined economic net returns for corn using glyphosate technology were similar to those of corn produced with conventional herbicide systems. However, Thelen and Penner [8] reported slight yield reductions in corn grain yields with the application of glyphosate under certain temporal high-yield environments. Krausz et al. [9] reported that height and grain yield of a glufosinateammonium-resistant corn hybrid was not different from a nonresistant isoline grown using a conventional herbicide for weed control.

Tharp and Kells [10] found that corn yields of herbicide resistant hybrids were greatest with rates of $0.84 \mathrm{~kg}_{\text {ae ha }}{ }^{-1}$ of Glyphosate and $0.41 \mathrm{~kg}$ ai ha ${ }^{-1}$ of glufosinate ammonium when applied at growth stage V5 [11], as opposed to rates of $0.21 \mathrm{~kg}$ ae ha ${ }^{-1}$ for glyphosate and $0.18 \mathrm{~kg}$ ai ha ${ }^{-1}$ for glufosinate ammonium. They also reported that weed control with herbicide applications at growth stage V3 followed by cultivation, were as effective in controlling weeds as herbicide-only treatments applied at growth stage V5. Gower et al. [1] reported both weed control and grain yields of several corn hybrids grown in a multi-state experiment, was considerably more variable when glyphosate was applied only once. Grain yields were highest with two herbicide applications, the first being applied when weeds were only $5 \mathrm{~cm}$ tall.

Aflatoxin, a secondary product of Aspergillus flavus and fumonisin produced by the fungus Fusarium verticillioides (Sacc.) Nirenberg. are both potential carcinogens that contaminate corn grain in crops grown under stress [12]. Weeds effectively compete with corn for water, sunlight, and nutrients and are capable of inducing considerable stress to the crop $[13,14]$. Some weed species can also induce stress on corn through allelopathy [15]. Glufosinate ammonium has been reported in some studies to reduce the incidence of aflatoxin in corn grain when applied late in the growing season $[16,17]$. No evidence though exists concerning its effects on aflatoxin or fumonisin when applied earlier and solely for weed control purposes.

Much of the research on corn and the effects of herbicides have focused on weed control and grain yields. Little or no information is currently available on how herbicide applications may affect growth and development of corn plants that have resistance to a particular herbicide independent of the impact controlling weeds has on the crop. Glyphosate resistant soybean (Glycine max L. Merr.) cultivars tended to yield less seed than conventional cultivars when this technology was first introduced [18]. Rather than evaluate weed control, the objective of this experiment was to determine if glyphosate applied at labeled recommendations, alters the development of resistant corn hybrids during the growing season compared to being grown with no herbicide and cultivated for weed control. A glufosinate-ammonium resistant hybrid and a conventional hybrid treated with atrazine were included for comparison. Determinations were also made on the effects weed control method may have upon aflatoxin and fumonisin contamination of the grain.

\section{Materials and Methods}

The experiment was conducted during the 2005, 2006, and 2007 growing seasons at the Mississippi State University Delta Branch Experiment Station at Stoneville, MS. The experimental design was a randomized complete block replicated four times. Individual experimental units were six rows, $9 \mathrm{~m}$ long, spaced $102 \mathrm{~cm}$ apart and consisted of one of six corn hybrids and either a herbicide treatment or mechanical cultivation for weed control. The six corn hybrids used in the experiment are listed in Table 1, along with their maturity and herbicide resistance.

Soil at the experimental site was a Beulah fine sandy loam (coarse-loamy, mixed thermic Typic Dystrochrepts). Site preparation involved forming $50 \mathrm{~cm}$ high ridges spaced $102 \mathrm{~cm}$ apart in late winter. The previous crop each year of the study was corn. Supplemental fertilizer was applied yearly to a yield goal of $12 \mathrm{Mg} \mathrm{ha}^{-1}$ with approximately $112 \mathrm{~kg} \mathrm{Nha}^{-1}$ as a urea: $\mathrm{NH}_{4} \mathrm{NO}_{3}$ liquid applied prior to planting and an additional $112 \mathrm{~kg} \mathrm{Nha}^{-1}$ side dressed at growth stage V6. Planting occurred 21 April, 14 April, and 3 April in 2005, 2006, and 2007, respectively. Seeding rates were at 9 kernels $\mathrm{m}^{-1}$ of row with an expected final population of 86500 plants ha ${ }^{-1}$.

The experiment was furrow irrigated 5 May, 10 June, and 20 June 2005 with approximately $25.0 \mathrm{~mm}$ of water applied at each irrigation using a schedule previously reported by Bruns et al. [19]. The 2006 planting was irrigated on 5 June, 17 June, and 13 July and the 2007 planting on 25 May, 4 June, and 13 June.

Atrazine was applied to the herbicide treated plots of $31 \mathrm{G} 98$ post emergence to both the crop and some weeds at growth stage V3 for the corn. Rate of herbicide application for the atrazine treatment was $2.24 \mathrm{~kg}_{\text {ai ha }}{ }^{-1}$ and included $4.4 \mathrm{~L} \mathrm{ha}^{-1}$ of crop oil. Glufosinate ammonium was applied to the herbicide treated plots of 34A55 post-emergence at 
growth stage V5 at a rate of $3.65 \mathrm{~kg} \mathrm{aeha}^{-1}$. Glyphosatetreated plots were sprayed at growth stage V5 at a rate of $0.8 \mathrm{~kg}$ ae ha ${ }^{-1}$. All herbicide treatments were applied with a $\mathrm{CO}_{2}$ pressurized plot sprayer. Cultivated plots were first hand-hoed at growth stage $\mathrm{V} 3$, then machine cultivated at growth stage V6, and hand-hoed again at growth stage V8.

Data on leaf area index (LAI) and total plant dry weight were collected weekly, weather permitting, beginning at growth stage V3 until growth stage R1. Accumulated Growing Degree Units at a $10 \mathrm{C}$ base (GDU10) for each sampling date of the three years of the experiment were calculated from weather data collected within $0.5 \mathrm{~km}$ of the site [20] using the formula described by Shaw in [21]. In 2005, LAI for each plot was estimated by harvesting one plant, at random from rows 2 and 5 each week, and measuring area of individual leaves using a Li-Cor 3100 leaf area meter (Linclon, NE). Harvested plant material was then dried at $50 \mathrm{C}$ for at least 72 hours and total plant dry weight determined. Beginning in 2006 LAI was estimated using an AccuPAR LP-80 PAR/LAI ceptometer (Decagon Devices, Pullman, WA). Six readings from random areas within the two center rows of each plot (rows 3 and 4) were recorded and the mean LAI determined. One randomly selected plant was also harvested weekly from rows 2 and 5 of each plot to determine total plant dry matter. Sampling was done so as not to select a plant adjacent to one that had been previously harvested. These data were later used to calculate crop growth rate (CGR) and relative growth rate (RGR) using formulas reported by Brown [22]. Beginning one week after anthesis and continuing until growth stage R6, only developing ears were harvested for dry matter determination.

Approximately $5 \mathrm{wk}$ after physiological maturity population counts were made in the middle $5 \mathrm{~m}$ of the two center rows (rows 3 and 4), ears were hand harvested, and shelled using a gasoline powered stationary sheller to determine grain yield. Weights were recorded and a $1 \mathrm{~kg}$ grain sample collected for grain moisture content, bulk density, kernel weight, and mycotoxin determinations. Yields were adjusted to a $155 \mathrm{mg} \mathrm{kg}^{-1}$ standard moisture level. Aflatoxin contamination levels of the grain were determined by high-performance liquid chromatography using procedures described by Sobolev and Dorner [23]. Fumonisin contamination was determined using procedures reported by Abbas et al. [24].

Data were analyzed using procedures available through the Statistical Analysis System Version 9.1 (SAS Institute, Research Triangle, NC). Leaf area index and dry weight accumulation data were analyzed using PROC MIXED with Type III Tests of Fixed Effects. Grain yields, kernel weights, kernels per ear, and mycotoxin data were analyzed using PROC MIXED.

\section{Results and Discussion}

Seasonal precipitation contrasted markedly during the experiment, especially after anthesis, which for most hybrids occurred on 15 June, 12 June, and 14 June for 2005, 2006, and 2007, respectively [10]. Combined totals of both rainfall and

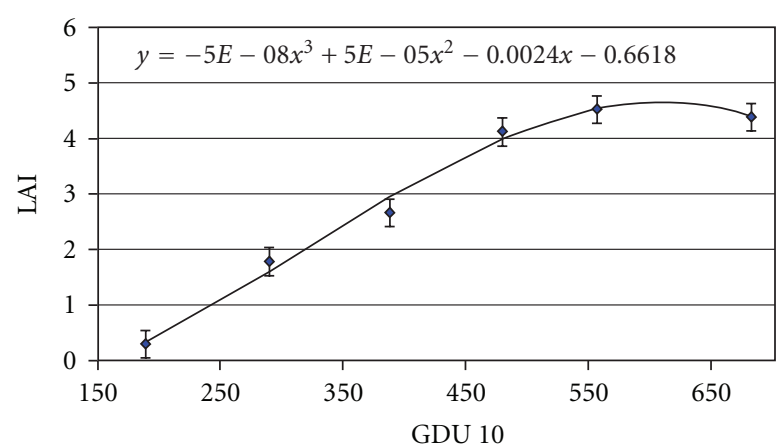

FIgURE 1: Leaf Area Index Development of Six Corn Hybrids (Four Glyphosate Resistant, One Glufosinate-Ammonium Resistant, and one Atrazine Resistant) Grown at Stoneville, MS in 2005 and Treated with Herbicides or Cultivated for Weed Control.

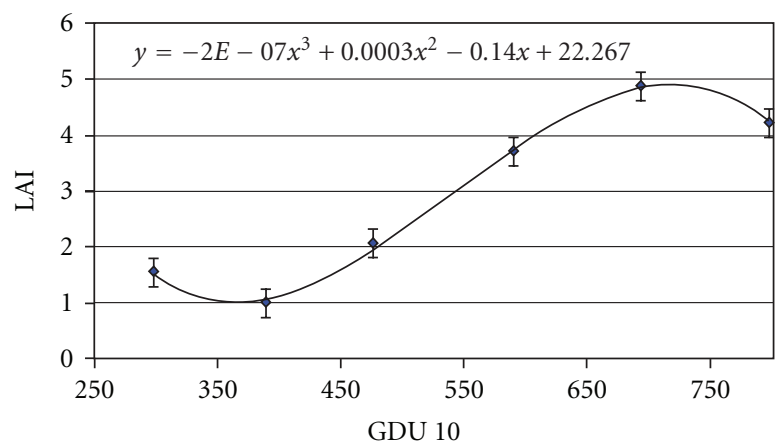

Figure 2: Leaf Area Index Development of Six Corn Hybrids (Four Glyphosate Resistant, One Glufosinate-Ammonium Resistant, and one Atrazine Resistant) Grown at Stoneville, MS in 2006 and Treated with Herbicides or Cultivated for Weed Control.

irrigation water during this time were $104.6 \mathrm{~mm}, 78.6 \mathrm{~mm}$, and $214.6 \mathrm{~mm}$ in 2005,2006 , and 2007 , respectively. Heat stress was not likely a major factor during the experiment although three days near the end of the 2006 growing season, 16 July, 19 July, and 20 July exceeded $36 \mathrm{C}$.

Individual sampling periods as days after planting (DAP) and the corresponding GDU 10 are presented in Table 2. Analyses of LAI data combined over years revealed a significant $(f=5.6 ; d f=1,535 ; P \leq .01)$ year*hybrid*weed control*sp interaction. Thus, years were analyzed separately. Changes in LAI within a given year of the experiment did not differ between the two weed control methods or hybrids (Table 3). Glyphosate, glufosinate ammonium, nor atrazine adversely affected the available photosynthetic area of their respective resistant hybrids. Differences in the rate of change in LAI however, were noted among the growing seasons of the experiments thus, resulting in the previously noted significant interaction (Table 3). Data on LAI from 2005 indicated a significant $(P \leq .01)$ third degree polynomial best explained the change in LAI from growth stage V3 to growth stage R1. No such differences were observed in 2006 or 2007 but, for comparative purposes similar curves were developed (Figures 1, 2, and 3). A decline in LAI at anthesis from the last measurements taken during vegetative growth 
TABle 2: Sampling Periods (days after planting (DAP)) and Accumulated Growing Degree Units 10 C base (GDU10's) for LAI and Dry Weight Accumulation of Herbicide Resistant Corn Hybrids Grown at Stoneville, MS.

\begin{tabular}{|c|c|c|c|c|c|}
\hline \multicolumn{2}{|c|}{2005} & \multicolumn{2}{|c|}{2006} & \multicolumn{2}{|c|}{2007} \\
\hline DAP & GDU10's & DAP & GDU10's & DAP & GDU10's \\
\hline 22 & 189 & 25 & 298 & 27 & 352 \\
\hline 30 & 290 & 34 & 389 & 33 & 436 \\
\hline 37 & 388 & 40 & 476 & 39 & 492 \\
\hline 44 & 480 & 47 & 590 & 46 & 592 \\
\hline 49 & 557 & 54 & 693 & 53 & 691 \\
\hline 57 & 683 & 61 & 797 & 60 & 802 \\
\hline
\end{tabular}

Table 3: Type III Test of Fixed Effects of Two Methods of Weed Control on LAI of Herbicide Resistant Corn Hybrids Grown at Stoneville, MS for Three Years. ${ }^{\dagger}$

\begin{tabular}{|c|c|c|c|c|c|c|c|}
\hline \multirow[t]{2}{*}{ Source } & \multirow[t]{2}{*}{$\mathrm{DF}$} & \multicolumn{2}{|c|}{2005} & \multicolumn{2}{|c|}{2006} & \multicolumn{2}{|c|}{2007} \\
\hline & & $\mathrm{F}$ & $P>\mathrm{F}$ & $\mathrm{F}$ & $P>\mathrm{F}$ & $\mathrm{F}$ & $P>\mathrm{F}$ \\
\hline Hybrid & 5 & .8 & .56 & .09 & .99 & .16 & .98 \\
\hline Weed control & 1 & .2 & .65 & .26 & .61 & .44 & .51 \\
\hline Hybrid*Weed control & 5 & .86 & .52 & .25 & .93 & .56 & .73 \\
\hline $\mathrm{xsp}$ & 1 & 19.96 & $\leq .01$ & 1.32 & .25 & .06 & .81 \\
\hline xsp* xsp & 1 & 63.22 & $\leq .01$ & 1.06 & .31 & .27 & .61 \\
\hline $\mathrm{xsp}^{*} \mathrm{xsp}^{*} \mathrm{xsp}$ & 1 & 87.71 & $\leq .01$ & 2.93 & .09 & .23 & .63 \\
\hline xsp ${ }^{*}$ Weed control & 1 & .32 & .57 & .31 & .58 & .56 & .45 \\
\hline xsp* ${ }^{*}$ sp $^{*}$ Weed control & 1 & .49 & .48 & .36 & .55 & .53 & .47 \\
\hline $\mathrm{xsp}^{*} \mathrm{xsp}^{*} \mathrm{xsp}^{*}$ Weed control & 1 & .64 & .42 & .46 & .50 & .51 & .48 \\
\hline xsp*Hybrid & 5 & .9 & .48 & .09 & .99 & .16 & .98 \\
\hline xsp* xsp*Hybrid & 5 & .89 & .49 & .09 & .99 & .17 & .97 \\
\hline \multirow[t]{2}{*}{$\mathrm{xsp}^{*} \mathrm{xsp}^{*} \mathrm{xsp}^{*}$ Hybrid } & 5 & .84 & .52 & .12 & .99 & .19 & .96 \\
\hline & & & Estimate & & Estimate & & Estimate \\
\hline$\sigma$ Replication & & & .012 & & .02 & & .03 \\
\hline$\sigma$ Replication*Hybrid*Weed control & & & .018 & & .01 & & .09 \\
\hline$\sigma$ Hybrid $^{*}$ Weed control* ${ }^{*} \mathrm{pp}$ & & & .027 & & .12 & & .23 \\
\hline$\sigma$ Residual & & & .16 & & .29 & & .32 \\
\hline
\end{tabular}

${ }^{\dagger}$ Weed control methods consisted of either cultivation and hand-hoeing or applications of labeled quantities of glyphosate, glufosinate ammonium, or atrazine. Hybrids were DKC 60-17RR, DKC 60-19RR, G8118RR, 31G98, 34A55LL, G8287RR (2005 and 2006), and G8270RR (2007).

occurred in 2005 and 2006 but not in 2007. Boedhram et al. [25] observed a similar change in some of their LAI data of corn grown in the northwestern Corn Belt.

A decline in LAI between the observation at $298 \mathrm{GDU}$ 10 and at 389 GDU 10 was observed in 2006. This likely occurred because LAI data acquisition at 389 GDU 10 could not begin until 13:00 CDT due to a scattered to broken cloud cover during the morning that interfered with light needed by the ceptometer to estimate LAI. By 13:00 CDT the plants were evidently experiencing sufficient water stress to cause the leaves to lose turgor, wilt slightly, and thus not intercept light to their full potential. All other LAI data were acquired between 9:00 CDT and 11:00 CDT.

Rate of dry matter accumulation (DMA) for the whole plant averaged among all treatments prior to anthesis occurred at rates similar to those previously reported (Figure 4) [11]. The main effect of weed control method and any subsequent interactions with hybrids or years were not statistically significant with any of the DMA data. Similarly, data on weed control, hybrids, nor their interactions were statistically significant for CGR and RGR (data not shown). Differences in these data were observed among years (Table 4). However, no consistency among treatments was observed. Crop growth rates and RGR's for the whole plant began to decline as the plants reached anthesis. Maturities of the hybrids used in this experiment did not demonstrate any measureable differences among DMA, CRG, or RGR. No trends were observed in DMA of the ears or kernels postanthesis and no differences in these data were observed among weed control methods (data not shown).

The hybrid $\times$ weed control interaction for grain yield was not statistically significant. Hybrid $x$ year and weed control $\times$ year interactions though were significant $(P \leq .01)$ for grain yield. Differences in yield were observed within individual 
Table 4: Crop Growth Rates $\left(\mathrm{gm}^{-1} d^{-1}\right)$ and Relative Growth Rates $\left(g g^{-1} d^{-1}\right)$ of Six Herbicide Resistant Corn Hybrids From Growth Stage V3 Until Growth Stage R1, Grown at Stoneville, MS. ${ }^{\dagger}$

\begin{tabular}{|c|c|c|c|c|c|c|c|c|c|c|}
\hline \multirow{2}{*}{ Year } & \multicolumn{5}{|c|}{ Sampling Interval } & \multicolumn{5}{|c|}{ Sampling Interval } \\
\hline & $1-2$ & $2-3$ & $3-4$ & $4-5$ & $5-6$ & $1-2$ & $2-3$ & $3-4$ & $4-5$ & $5-6$ \\
\hline & \multicolumn{5}{|c|}{$\mathrm{gm}^{-1} \mathrm{~d}^{-1}$} & \multicolumn{5}{|c|}{$\mathrm{gg}^{-1} \mathrm{~d}^{-1}$} \\
\hline 2005 & $10.9 \mathrm{a}$ & 20.4 & $45 a$ & $30.6 \mathrm{ab}$ & 30.1 & $0.9 \mathrm{a}$ & $0.6 \mathrm{a}$ & $0.5 \mathrm{ab}$ & $0.2 \mathrm{~b}$ & 0.3 \\
\hline 2006 & $5.2 \mathrm{~b}$ & 12.8 & $40.8 \mathrm{a}$ & $19.1 \mathrm{~b}$ & 33.4 & $0.5 b$ & $0.4 \mathrm{~b}$ & $0.6 \mathrm{a}$ & $0.2 b$ & 0.2 \\
\hline 2007 & $6.4 \mathrm{~b}$ & 18 & $21.2 \mathrm{~b}$ & $45.6 \mathrm{a}$ & 29.8 & $0.3 c$ & $0.5 b$ & $0.3 \mathrm{~b}$ & $0.4 \mathrm{a}$ & 0.2 \\
\hline
\end{tabular}

${ }^{\dagger}$ Means of 4 replications, 6 hybrids (DKC 60-17RR, DKC 60-19RR, G8118RR, 31G98, 34A55LL, G8287RR (2005 and 2006), and G8270RR (2007), and 2 weed control methods (herbicide or cultivation). Means within a column followed by the same letter are not significantly different by LSMeans $(P \leq .01)$. Means within a column not followed by a letter are not significantly different.

Table 5: Combined Mean Grain Yields of Herbicide Tolerant Corn Hybrids Grown With and Without Herbicide Application at Stoneville, MS. $^{\dagger}$

\begin{tabular}{lccc}
\hline & & Mgha $^{-1}$ & \\
\hline Hybrid $^{\ddagger}$ & 2005 & 2006 & 2007 \\
\hline DKC 60-17RR & 11.5 & 11.2 & 12 \\
DKC 60-19RR & 12.8 & 11.3 & 11.8 \\
G8118RR & 7 & 10.5 & 9.3 \\
G8287RR & 11.3 & 11.5 & $* * * * * *$ \\
G8270RR & $* * * * * *$ & $* * * * * *$ & 10.8 \\
31G98 & 11 & 9.7 & 12.6 \\
34A55LL & 10.8 & 8.6 & 11.5 \\
\hline
\end{tabular}

${ }^{\dagger}$ Hybrid means averaged across both herbicide and cultivated treatments replicated 4 times. $\operatorname{LSD}(P \leq .01)=1.5$ for comparing means within a column and within a row $\operatorname{LSD}(P \leq .01)=1.6$.

${ }^{\ddagger}$ Refer to Table 1 for hybrid information.

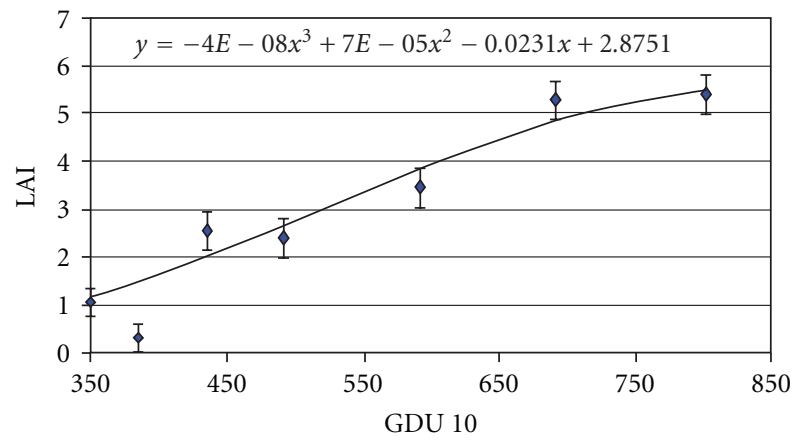

FIGURe 3: Leaf Area Index Development of Six Corn Hybrids (Four Glyphosate Resistant, One Glufosinate-Ammonium Resistant, and one Atrazine Resistant) Grown at Stoneville, MS in 2007 and Treated with Herbicides or Cultivated for Weed Control.

years among hybrids and across years for individual hybrids (Table 5). No particular hybrid consistently yielded better than any other during the course of this experiment, neither were yields for one year consistently greater than the other two. The significant weed control $\times$ year interaction resulted from the mean yield for herbicide treated plots in $2006\left(9.8 \mathrm{Mgha}^{-1}\right)$ being less than similarly treated plots in $2005\left(10.8 \mathrm{Mgha}^{-1}\right)$ and $2007\left(11.6 \mathrm{Mgha}^{-1}\right)$ and less than the cultivated plot $\left(11.2 \mathrm{Mgha}^{-1}\right)$ in 2006. No other differences were observed among these means (10.6 $\mathrm{Mgha}^{-1}$ and $11.1 \mathrm{Mgha}^{-1}$ for cultivate plots in 2005 and 2007, resp.).

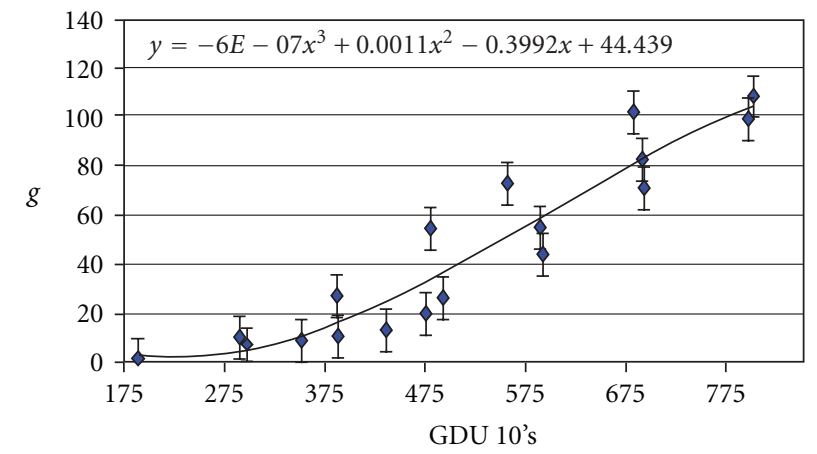

Figure 4: Dry Matter Accumulation per Plant (g) of Six Corn Hybrids (Four Glyphosate Resistant, One Glufosinate-Ammonium Resistant, and one Atrazine Resistant) From V3 to R1 Grown at Stoneville, MS in 2005, 2006, and 2007 and Treated with Herbicides or Cultivated for Weed Control.

Part of the reduced yield of herbicide treated plots in 2006 was due to plant populations being less that year $(P \leq .10)$ (79084 plants ha ${ }^{-1}$ ) than plant populations for similarly treated plots in 2005 (87072 plants ha ${ }^{-1}$ ) or 2007 (84 263 plants $\left.\mathrm{ha}^{-1}\right)$. A similar trend occurred with cultivated plots $(P \leq .10)\left(87072\right.$ plants ha ${ }^{-1}, 81657$ plants ha $^{-1}$, and 85411 plants ha ${ }^{-1}$ for 2005,2006 , and 2007, respectively) but with no adverse affect on yield. Mean kernel weight $(312 \mathrm{mg})$ was unaffected by hybrid differences, weed control method, or 
Table 6: Combined Mean Grain Bulk Density of Herbicide Tolerant Corn Hybrids Grown With and Without Herbicide Application at Stoneville, MS. ${ }^{\dagger}$

\begin{tabular}{lccc}
\hline & & $\mathrm{Kg} \mathrm{m}^{-1}$ & \\
\hline Hybrid $^{\ddagger}$ & 2005 & 2006 & 2007 \\
\hline DKC 60-17RR & 714.3 & 732.3 & 727.2 \\
DKC 60-19RR & 719.4 & 725.9 & 734.9 \\
G8118RR & 731.0 & 732.3 & 725.9 \\
G8287RR & 718.1 & 714.3 & $* * * * * *$ \\
G8270RR & $* * * * *$ & $* * * * * *$ & 740.0 \\
31G98 & 743.9 & 747.7 & 741.3 \\
34A55LL & 760.6 & 764.5 & 769.6 \\
\hline
\end{tabular}

${ }^{\dagger}$ Hybrid means averaged across both herbicide and cultivated treatments replicated 4 times. LSD $(P \leq .01)=16.7$ for comparing means within a column and a row.

${ }^{\ddagger}$ Refer to Table 1 for hybrid information.

TABle 7: Combined Mean Aflatoxin and Fumonisin Contamination of Herbicide Tolerant Corn Hybrids Grown With and Without Herbicide Application at Stoneville, MS.

\begin{tabular}{|c|c|c|c|c|}
\hline \multirow{2}{*}{ Hybrid ${ }^{\S}$} & \multicolumn{2}{|c|}{$\begin{array}{c}\text { Aflatoxin } \\
\mathrm{ngg}^{-1}\end{array}$} & Fumonisin $^{\ddagger}$ & \multirow[b]{2}{*}{$\mathrm{mg} \mathrm{kg}^{-1}$} \\
\hline & 2005 & 2006 & Year & \\
\hline DKC 60-17RR & 74.8 & 27.9 & 2005 & 5.8 \\
\hline DKC 60-19RR & 109.9 & 30.8 & 2006 & 9.8 \\
\hline G8118RR & 21.3 & 15.3 & 2007 & 1.1 \\
\hline G8287RR & 32.8 & 18.8 & & \\
\hline $31 \mathrm{G} 98$ & 36.4 & 25.1 & & \\
\hline 34A55LL & 31.1 & 18.3 & & \\
\hline
\end{tabular}

${ }^{\dagger}$ Hybrid means averaged across both herbicide and cultivated treatments replicated four times. Means within a column and a row LSD $(P \leq .01=37.7)$. No aflatoxin was detected in 2007.

${ }^{\ddagger}$ Means of 6 hybrids, two weed control treatments and 4 replications. Means are significantly different $(P \leq .01)$.

$\S$ Refer to Table 1 for Hybrid information.

growing season. Observed differences in grain yield were a result of plants ha ${ }^{-1}$ and/or kernels plant ${ }^{-1}$.

Grain bulk density was unaffected by weed control method. The glufosinate-ammonium resistant hybrid (34A55LL) had significantly greater grain bulk density than most all hybrids all three years of the experiment (Table 6). The atrazine only resistant hybrid (31G98) also had greater grain bulk density than the least dense hybrids in 2005 and 2006 but not in 2007. However, the lowest grain bulk density $\left(714.3 \mathrm{kgm}^{-3}\right)$ observed in the entire experiment was above the $695 \mathrm{~kg} \mathrm{~m}^{-3}$ minimum required for corn grain to grade U.S. no. 2 yellow, the most common grade traded on the world market [26].

Aflatoxin contamination was found in grain samples in 2005 and 2006 but not in 2007. Considerable rainfall during grain filling in 2007 [20] likely contributed to the lack of aflatoxin that season. The hybrid $\times$ year interaction for the two years for which aflatoxin contamination occurred was statistically significant $(P \leq .01)$. The levels of aflatoxin for both DKC 60-17 and DKC 60-19 were greater in 2005 than in 2006 and greater than the other hybrids in the experiment in 2005 (Table 7). No other significant differences were noted in this interaction nor was the main effect or interactions involving weed control method statistically significant.
Mean fumonisin contamination differed significantly $(P \leq .01)$ during the three years of the experiment (Table 7). The observed levels for 2005 and 2006 exceeded recommended levels for food and equine feed, but not for other livestock [27]. No differences among hybrids, weed control method, or their interactions were noted for any of the three years. The low contamination level observed for 2007 can likely be attributed to the abundance of rainfall and the lack of heat stress during kernel filling as previously noted for that year.

These data demonstrate that the application of herbicides, particularly glyphosate to glyphosate resistant corn hybrids, has no negative impact upon the growth, development, and yield of the crop. Herbicide application also has no influence upon mycotoxin contamination of corn based upon these data. Glyphosate and glufosinate-ammonium resistant corn hybrids can be part of a weed management program in a humid subtropical environment such as the Mid South USA with no loss in yield or grain quality.

\section{References}

[1] S. A. Gower, M. M. Loux, J. Cardina et al., "Effect of postemergence glyphosate application timing on weed control 
and grain yield in glyphosate-resistant corn: results of a 2-yr multistate study," Weed Technology, vol. 17, no. 4, pp. 821-828, 2003.

[2] National Agricultural Statistics Service-USDA, "Agriculture chemical use data base," September 2007, http://www .pestmanagement.info/nass/act_dsp_usage_multiple.cfm.

[3] J. L. Rubin, C. G. Gaines, and R. A. Jensen, "Enzymological basis for herbicidal action of glyphosate," Plant Physiology, vol. 70, pp. 833-839, 1982.

[4] M. Leason, D. Cunliffe, D. Parkin, P. J. Lea, and B. J. Miflin, "Inhibition of pea leaf glutamine synthetase by methionine sulphoximine, phosphinothricin and other glutamate analogues," Phytochemistry, vol. 21, no. 4, pp. 855-857, 1982.

[5] M. Lacuesta, A. Munoz-Rueda, C. Gonzalez-Murua, and M. N. Sivak, "Effect of phosphinothricin (glufosinate) on photosynthesis and chlorophyll fluorescence by barley leaves illuminated under photorespiratory and non-photorespiratory conditions," Journal of Experimental Botany, vol. 43, pp. 159$165,1992$.

[6] T. W. Goodwin and E. I. Mercer, Introduction to Plant Biochemistry, Pergamon Press, New York, NY, USA, 2nd edition, 1983.

[7] J. A. Ferrell and W. W. Witt, "Comparison of glyphosate with other herbicides for weed control in corn (Zea mays): efficacy and economics," Weed Technology, vol. 16, pp. 701-706, 2002.

[8] K. D. Thelen and D. Penner, "Yield environment affects glyphosate-resistant hybrid response to glyphosate," Crop Science, vol. 47, no. 5, pp. 2098-2107, 2007.

[9] R. F. Krausz, G. Kapusta, J. L. Matthews, J. L. Baldwin, and J. Maschoff, "Evaluation of glufosinate-resistant corn (Zea mays) and glufosinate: efficacy on annual weeds," Weed Technology, vol. 13, no. 4, pp. 691-696, 1999.

[10] B. E. Tharp and J. J. Kells, "Influence of herbicide application rate, timing, and interrow cultivation on weed control and corn (Zea mays) yield in glufosinate-resistant and glyphosateresistant corn," Weed Technology, vol. 13, no. 4, pp. 807-813, 1999.

[11] S. W. Ritchie, J. J. Hanway, and G. O. Benson, "How a corn plant develops," Special Report 48, Iowa State University of Science and Technology, Cooperative Extension Service, Ames, Iowa, USA, 1997.

[12] H. A. Bruns, "Controlling aflatoxin and fumonisin in maize by crop management," Journal of Toxicology, vol. 22, no. 2-3, pp. 153-173, 2003.

[13] W. Y. Cobb, Aflatoxin in the Southeastern United States: Was 1977 Exceptional?vol. 43, Quarterly Bulletin of the Association of Food and Drug Office, 1979.

[14] E. B. Lillehoj, "Effect of environmental and cultural factors on aflatoxin contamination of developing corn kernels," in Aflatoxin and Aspergillus flavus in Corn, U. L. Diener, R. L. Asquith, and J. W. Dickens, Eds., Southern Cooperative Extension Service Bulltin 279, pp. 27-34, Alabama Agricultural Experiment Station, Auburn University, Auburn, Ala, USA, 983.

[15] E. L. Rice, Allelopathy, Academic Press, Orlando, Fla, USA, 2nd edition, 1984.

[16] K. E. Damann and K. M. Tubajika, "Aflatoxin reduction in Liberty herbicide treatment of Liberty Link corn," in Proceedings of the Aflatoxin/Fumonisin Workshop, p. 89, USDAARS, Yosemite, Calif, USA, October 2000.

[17] K. M. Tubajika and K. E. Damann Jr., "Glufosinateammonium reduces growth and aflatoxin $B_{1}$ production by Aspergillus flavus," Journal of Food Protection, vol. 65, no. 9, pp. 1483-1487, 2002.
[18] J. Lundvall, K. Whigham, M. Westgate, and D. Farnham, "Roundup ready and conventional soybean yield comparison," Tech. Rep. ISRF00-34, Iowa State University, Southwest Research and Demonstration Farm, 2001, http:// www.ag.iastate.edu/farms/2000reports/se/RoundupReadyvs .Conventio.pdf.

[19] H. A. Bruns, W. R. Meredith, and H. K. Abbas, "Effects of furrow irrigation on corn in the humid sub-tropical Mississippi delta," Crop Management, 2003.

[20] Mississippi State University Extension Service, "Mississippi Weather Station Data," February 2008, http://ext.msstate .edu/anr/drec/stations.cgi.

[21] R. H. Shaw, "Climate requirement," in Corn and Corn Improvement, G. F. Sprague and J. W. Dudley, Eds., p. 617, American Society of Agronomy, Madison, Wis, USA, 3rd edition, 1988.

[22] R. H. Brown, "Growth of a green plant," in Physiological Basis of Crop Growth and Development, M. B. Tesar, Ed., pp. 153174, ASA, CSSA, Madison, Wis, USA, 1984.

[23] V. S. Sobolev and J. W. Dorner, "Cleanup procedure for determination of aflatoxins in major agricultural commodities by liquid chromatography," Journal of AOAC International, vol. 85, no. 3, pp. 642-645, 2002.

[24] H. K. Abbas, W. P. Williams, G. L. Windham, H. C. Pringle III, W. Xie, and W. T. Shier, "Aflatoxin and fumonisin contamination of commercial corn (Zea mays) hybrids in Mississippi," Journal of Agricultural and Food Chemistry, vol. 50, no. 18, pp. 5246-5254, 2002.

[25] N. Boedhram, T. J. Arkebauer, and W. D. Batchelor, "Seasonlong characterization of vertical distribution of leaf area in corn," Agronomy Journal, vol. 93, no. 6, pp. 1235-1242, 2001.

[26] USDA Grain Inspection, Packers, and Stockyards Administration, "US Corn Inspection," 2001, http://www.gipsa.usda.gov/ GIPSA/documents/GIPSA_Documents/corninspection.pdf. 


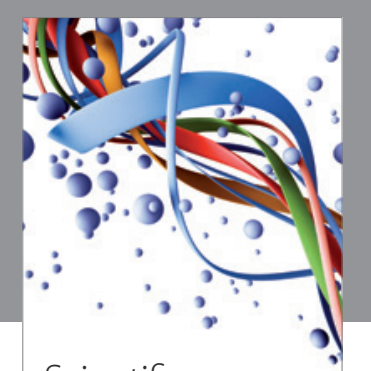

Scientifica
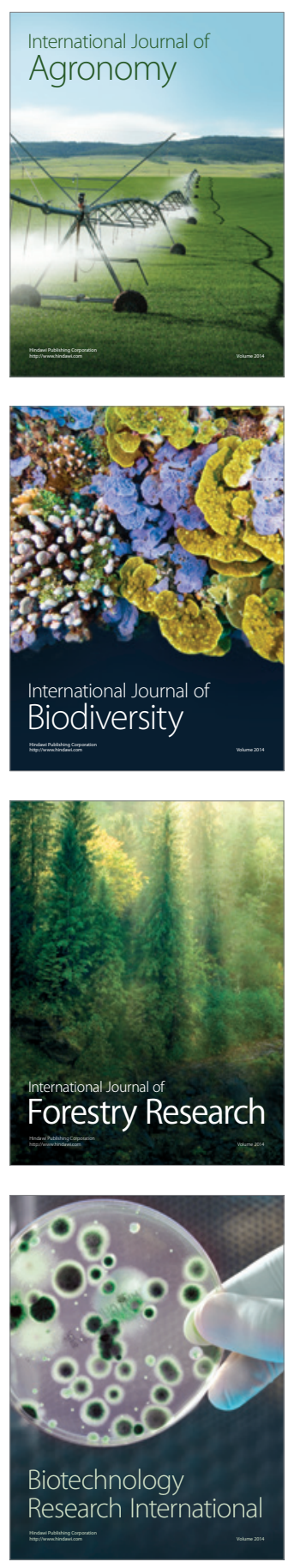
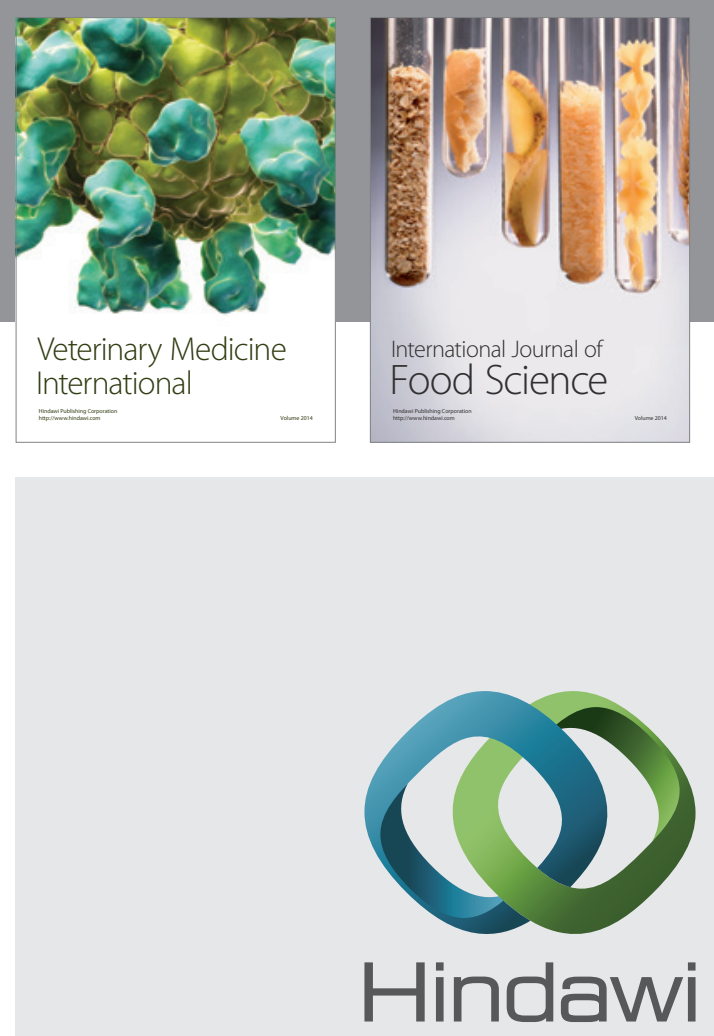

Submit your manuscripts at

http://www.hindawi.com
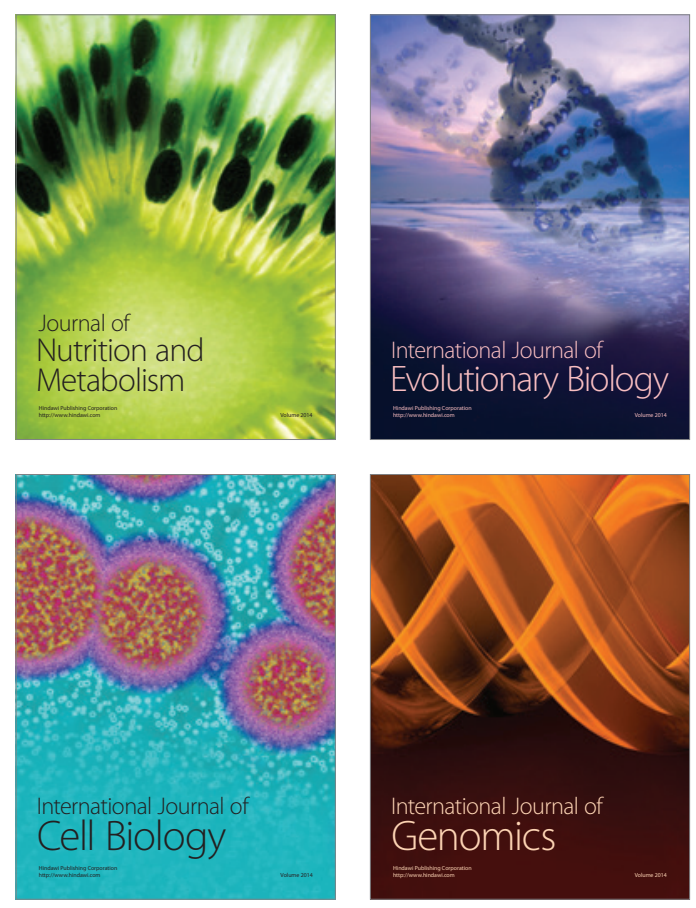
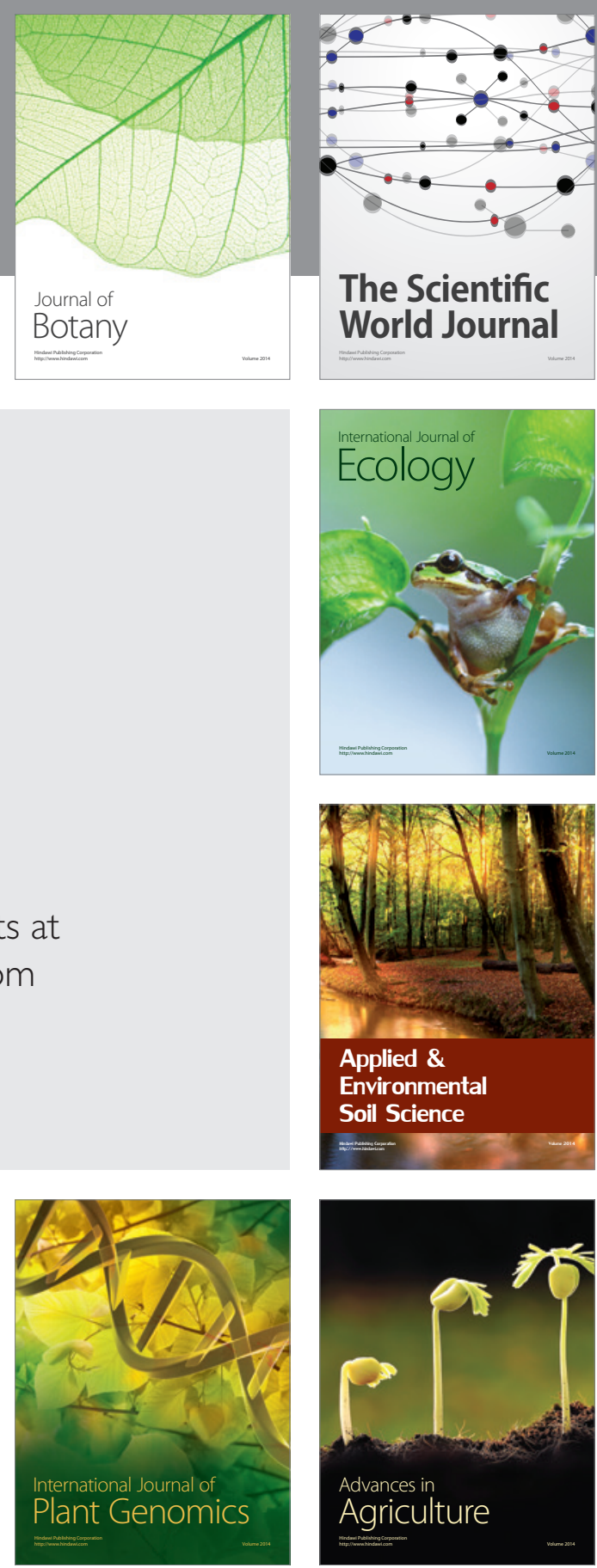

The Scientific World Journal
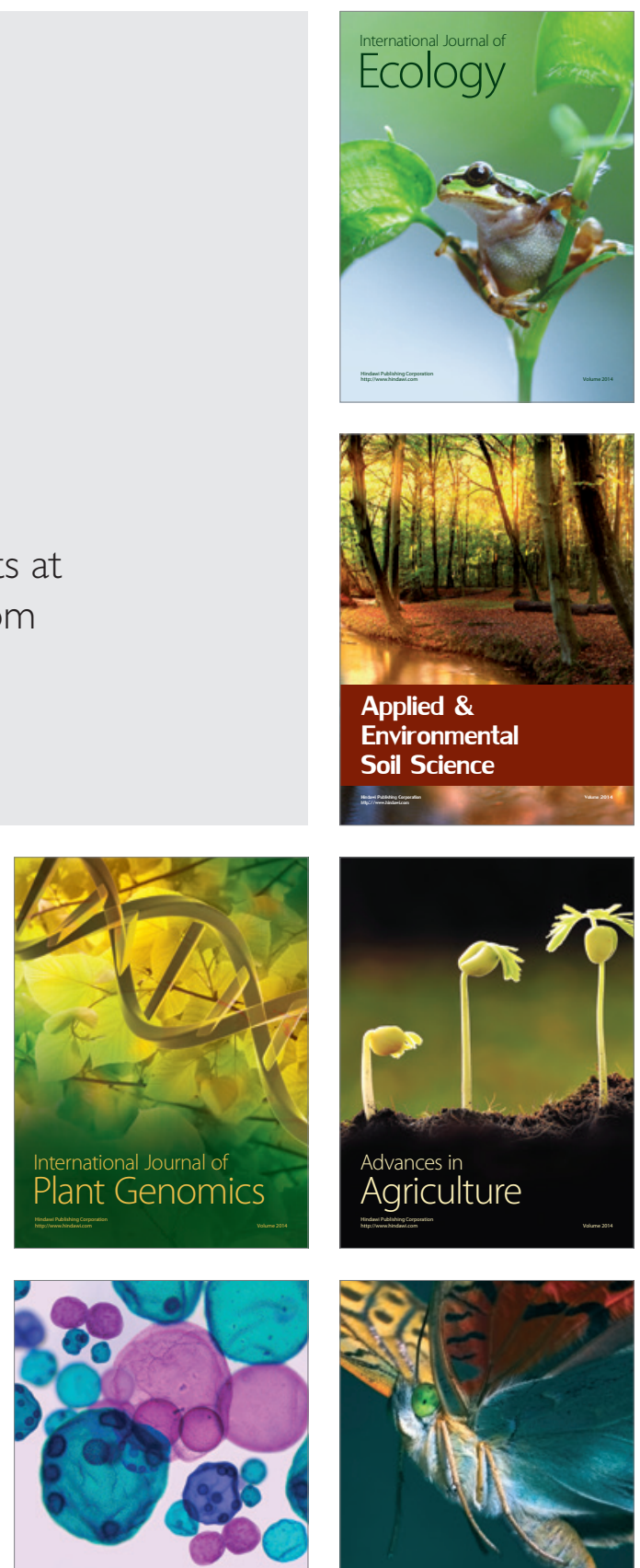

International Journal of Microbiology

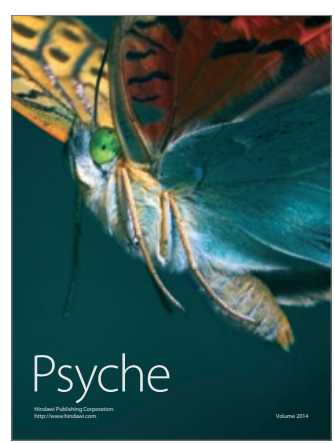

